\title{
Nexus between Artisanal and Small-Scale Gold Mining and Livelihood in Prestea Mining Region, Ghana
}

\author{
Francis Arthur, ${ }^{1}$ Williams Agyemang-Duah,, ${ }^{1}$ azak Mohammed Gyasi, ${ }^{1,2}$ \\ Joseph Yaw Yeboah, ${ }^{1}$ and Evans Otieku ${ }^{3}$ \\ ${ }^{1}$ Department of Geography and Rural Development, Faculty of Social Sciences, Kwame Nkrumah University of \\ Science and Technology, Kumasi, Ghana \\ ${ }^{2}$ Department of Sociology and Social Policy, Faculty of Social Sciences, Lingnan University, Tuen Mun, Hong Kong \\ ${ }^{3}$ Institute of Statistical, Social and Economic Research, University of Ghana, Legon, Accra, Ghana
}

Correspondence should be addressed to Francis Arthur; francisarthurholmes@rocketmail.com

Received 19 September 2015; Accepted 10 November 2015

Academic Editor: Manoj Khandelwal

Copyright (C) 2016 Francis Arthur et al. This is an open access article distributed under the Creative Commons Attribution License, which permits unrestricted use, distribution, and reproduction in any medium, provided the original work is properly cited.

\begin{abstract}
Drawing on the DFID's sustainable livelihood framework, this paper explores the nexus between artisanal and small-scale mining (ASM) and livelihood in Prestea mining region, Ghana. A cross-sectional mixed method survey involving simple random and purposively sampled participants $(N=151)$ was carried out. The results suggest both positive and negative relationships between ASM and livelihoods of the people. The study found various livelihood assets associated with ASM and how critical assets are adversely affected by ASM activities. Limited employment opportunities in rural areas (82\%), economic hardships/poverty situations of people (59\%), and "quick" income earnings from ASM (90\%) were the major factors that influenced people to combine and use their personal assets to enable them to engage in ASM. ASM contributes to the livelihood enhancement through income generation, increased well-being and asset acquisition (50.7\%), reduced vulnerabilities (31.1\%), and empowerment of people (19.2\%) to establish other economic activities. However, the small-scale miners and farmers as well as farmlands, forest, and water resources are most vulnerable to adverse effects of ASM activities. Accidents of various degrees, diseases, and death were the shocks in ASM. Regarding the massive impact of ASM on employment creation and poverty reduction in rural communities, it is recommended that stakeholders recast Ghana's mineral policy to ensure concurrent environmental sustainability and socioeconomic development.
\end{abstract}

\section{Introduction}

Countries that are endowed with mineral resources usually extract and use them to develop their economy for which Ghana is not an exception. Mining is practiced and exists in many countries [1]. Mining activities in the world have contributed immensely to the manufacturing sector via the provision of raw materials to secondary industries. Over the years, the extraction of precious minerals such as gold and diamond has led to a magnificent impact on the socioeconomic lives of people and communities involved directly or indirectly in the mining sector $[2,3]$. Mining, especially, artisanal and small-scale mining (ASM), represents a significant livelihood and source of income for rural communities and poverty-driven population in the world [4]. However, it has played a vital role in the development of Ghana, ranked second after South Africa in gold production [5].

The Collaborative Group on Artisanal and Small-Scale Mining (CASM) [6] observes that ASM employs and engages more people than large-scale gold mining and reduces the poverty levels in rural communities. ASM takes place all over the world but most notably in Africa, Asia, Oceania, and Central and South America [4]. Artisanal and smallscale mining (ASM) is poverty-driven activity and operated in rural and remote areas [7].

In Ghana, the mining sector directly contributed to $6 \%$ of Gross Domestic Product (GDP) and 27.6\% of government revenue in 2011 [8]. Ghana recorded a magnificent increase in all mineral productions in 2005 with gold rising and taking over from cocoa as Ghana's leading foreign exchange 
earner. In 2004, mineral revenue was $\$ 798$ million and increased to $\$ 995.2$ in 2005 contributing about $13 \%$ of the total revenue collected by Internal Revenue Service. Gold production had an increase of $63 \%$ with its export revenue increasing from $\$ 731.2$ million to $\$ 903.9$ million and that of diamond increased from $\$ 26$ million to $\$ 34.7$ million [9]. In Mongolia, the mining sector has contributed to about $17 \%$ of GDP, $65 \%$ of industrial value added, and $58 \%$ of export thereby making it the biggest contributor to the Mongolian economy [10].

In the entire world, mineral resource extraction through, particularly, artisanal gold mining plays a key role in the livelihood conditions of the people, hence, providing a means of living [11]. Datta et al. [12] indicated that livelihoods are means or ways of reducing poverty. However, different studies have indicated that mining results in different outcomes. Artisanal and small-scale mining takes different forms of contributions at both local and national level such as earnings from exports and making import of resource possible [13]. It provides significant livelihood for rural communities in Africa and serves as a means of alleviating poverty [6]. It also has a major impact on employment in developing countries, especially, in the rural areas where there are limited job opportunities [3]. It provides people the means of employment [2], since it does not involve any special skills. Hentschel et al. [11] indicated in their studies conducted in Bolivia that the reason for people's engagement in ASM operations is purposely to improve their livelihoods. Contrary to this, Mitullah et al. [14] argue that ASM diverts people's attention from agriculture due to low income earnings associated with farming activity and also lack of formal jobs and opportunities compels people to participate in it irrespective of the high risks involved. Hilson [15] in his studies in Ghana concluded that most of the small-scale miners are involved in gold extraction because it generates income quickly.

Studies amply show that not only are men engaged in ASM operations but also women participate in the activities [11]. According to Hentschel et al. [11], 75\% of those involved in ASM activities in Guinea are women while those of Ghana, South Africa, and Indonesia are 44\%, 5\%, and $10 \%$, respectively. Small-scale mining results in loss of source of livelihood of miners when they have accidents, which cause some miners to depend on their relatives for sustenance and assistance [5]. ASM is noted with its myriad of primary and secondary problems through land degradation, deforestation, air pollution, and water pollution [16].

Even though many people with various reasons of engagement in ASM have benefited from it, the various vulnerability contexts of the ASM and critical assets in ASM are not being demonstrated and investigated by mining researchers. With the increasing rate of ASM operations in Ghana, especially, Prestea mining area, the extent to which ASM affects livelihood of people and the community and contributes to livelihood enhancement is not well-indicated in empirical literature. This is because many studies in Ghana are based on environmental and health ramifications of mining [5, 17-21]. There is chronic dearth of empirical research and literature on the various connections between ASM and livelihood in Ghana. However, this current study was conducted to fill this gap and add to knowledge by exploring the nexus between ASM and livelihood in Prestea mining region (PMR) in Ghana using the sustainable livelihood approach.

\section{Data, Theoretical Approach, and Methods}

2.1. Research Setting. The study is based on a research conducted between October 2013 and June 2014 in Prestea mining enclave, Prestea-Huni Valley District (PHD) in the Western region of Ghana, to assess the nexus between ASM and livelihood. The Prestea-Huni Valley District is one of the newly created districts, which was carved out of the Wassa West District with Bogoso as its capital [22]. The communities of Prestea mining region are Prestea, Bondaye, and Himan (see Figures 1 and 2). The district has an estimated total population of 154,528 , of which males and females constitute 78,014 and 76,514, respectively [23]. Prestea mining area, Prestea, Bondaye, and Himan, has a total population of 40,607 . The study area forms approximately $26.7 \%$ of the district's total population. The district statistician indicated that the study area has the highest proportionate share of the population of the district. This is attributed to the increasing number of migrants from other parts of Ghana to engage in ASM activities in the area as well as the associated trading ventures. Other equally important factors such as poor acceptance rate of family planning, teenage pregnancy, and early marriage also account for the population increase over the years [22].

The topography of the area is generally undulating with few scarps ranging between $150 \mathrm{~m}$ and $300 \mathrm{~m}$ above sea level. Many rivers traversing the study communities could have maintained its relevance of providing the communities with source of water for domestic and irrigation purposes but the intensive operations of ASM have rendered them unsafe. The study area falls within the wet equatorial climate with average minimum temperature experience of about $26^{\circ} \mathrm{C}$ and a maximum temperature of $30^{\circ} \mathrm{C}$. The climatic condition of the study area is hot and humid, and it is characterized by seasonal weather patterns with double wet seasons [24]. The $\mathrm{PHD}$ is one of the districts that experience the highest rainfall in the country. It has a mean annual rainfall of $187.83 \mathrm{~cm}$. The rainy season is usually from March to July (major season) and from September to November (minor season). The rainy season has an important effect on the environment in creating watersheds, large expanse of stagnant water bodies, deep trenches, and gullies as well as leaching the nutrient content of the soil [22]. Rain water that fills dug holes and pits promotes breeding of mosquitoes and supports malaria vector growth. This is why Akabzaa and Darimani [5] stressed in their studies conducted in Tarkwa that there are always cases of malaria in mining communities. The PHD falls within the rainfall belt and exhibits wet moist evergreen rainforest with the height of trees ranging between 15 and 40 meters. The natural vegetation of the area is full of climbers and lianas, stranglers, which are able to reach the upper tree layer. ASM operations, particularly illegal mining, have gradually destroyed and altered the rich vegetation in the study area.

It also lies within the forest-dissected plateaus' physiographic region; Precambrian rocks of Birimian origin 


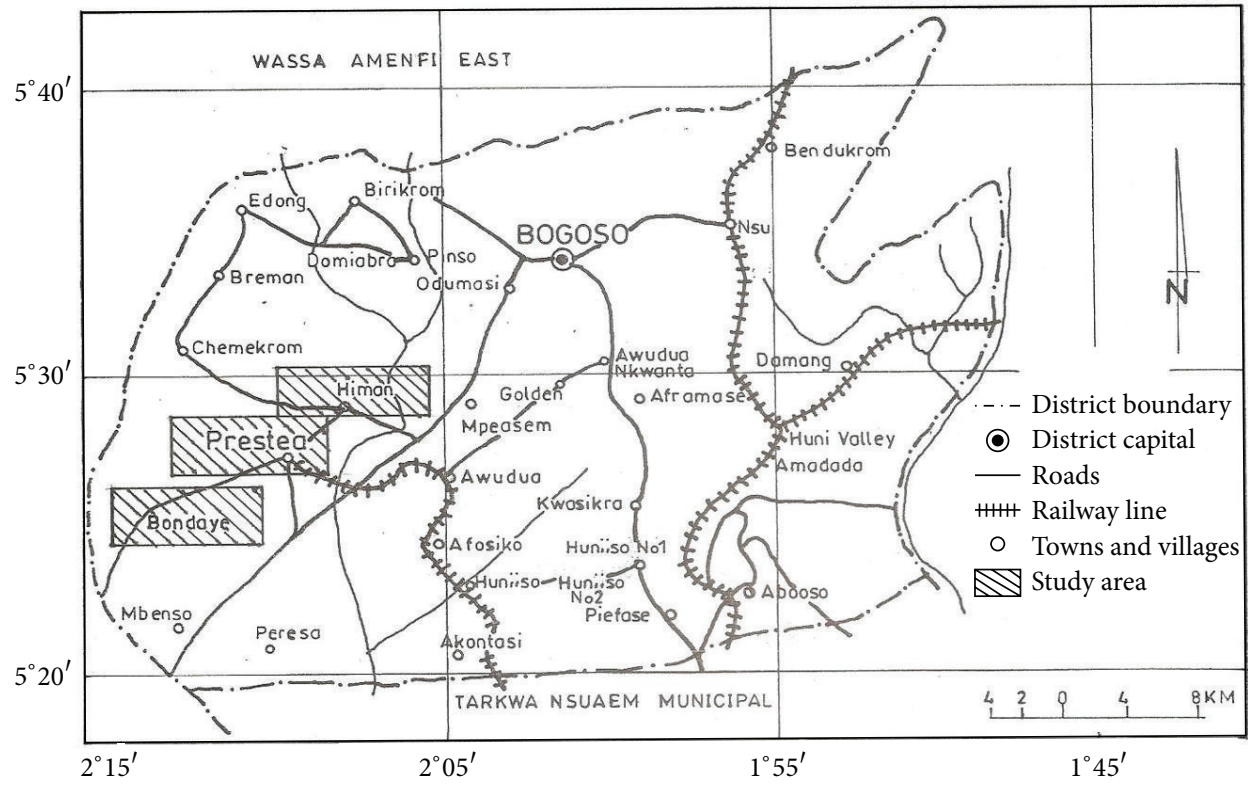

Source: Prestea-Huni Valley District Assembly

FIgURE 1: Map of Prestea-Huni Valley District showing the study communities. Source: Mapping Unit, Department of Geography and Rural Development, Kwame Nkrumah University of Science and Technology [25].

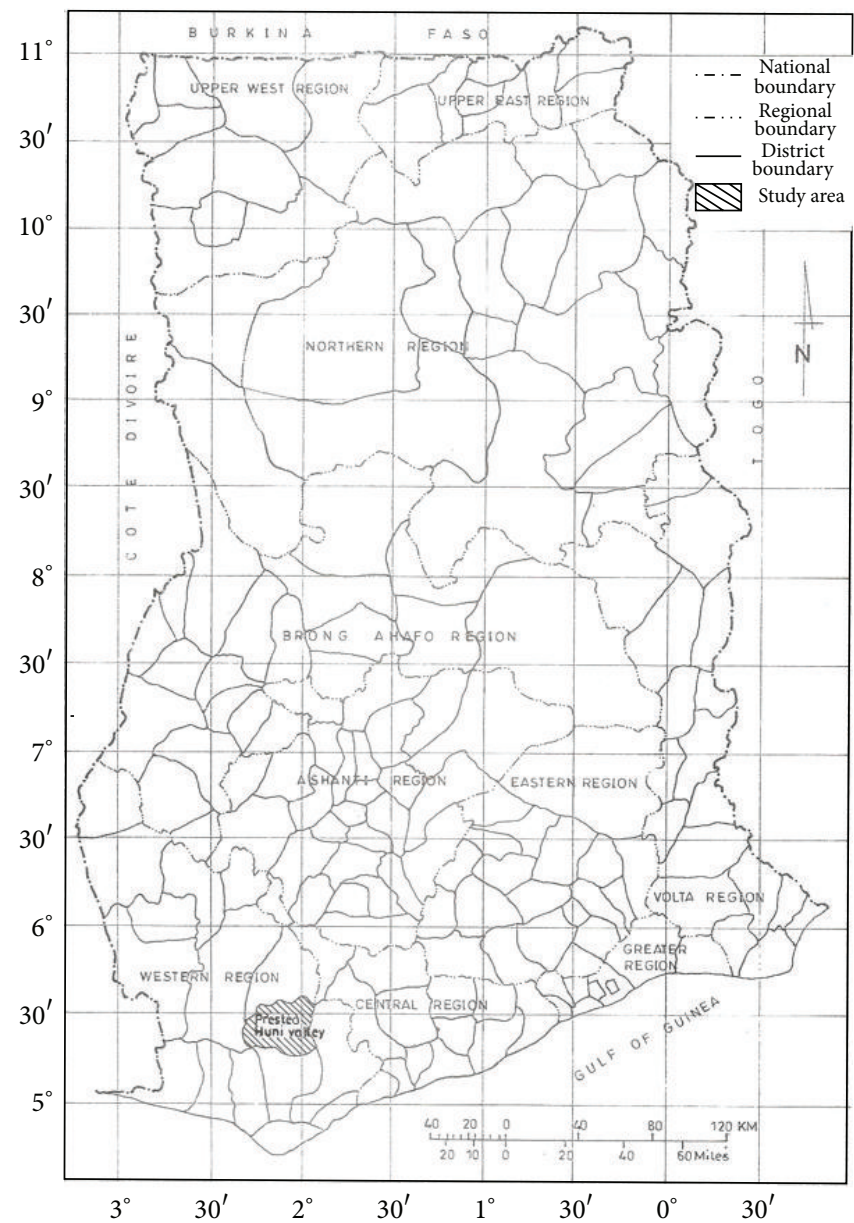

Source: Survey Dept. of Ghana (1994 Edition)

FIGURE 2: District map of Ghana showing the study district. Source: Mapping Unit, Department of Geography and Rural Development, Kwame Nkrumah University of Science and Technology [25]. 


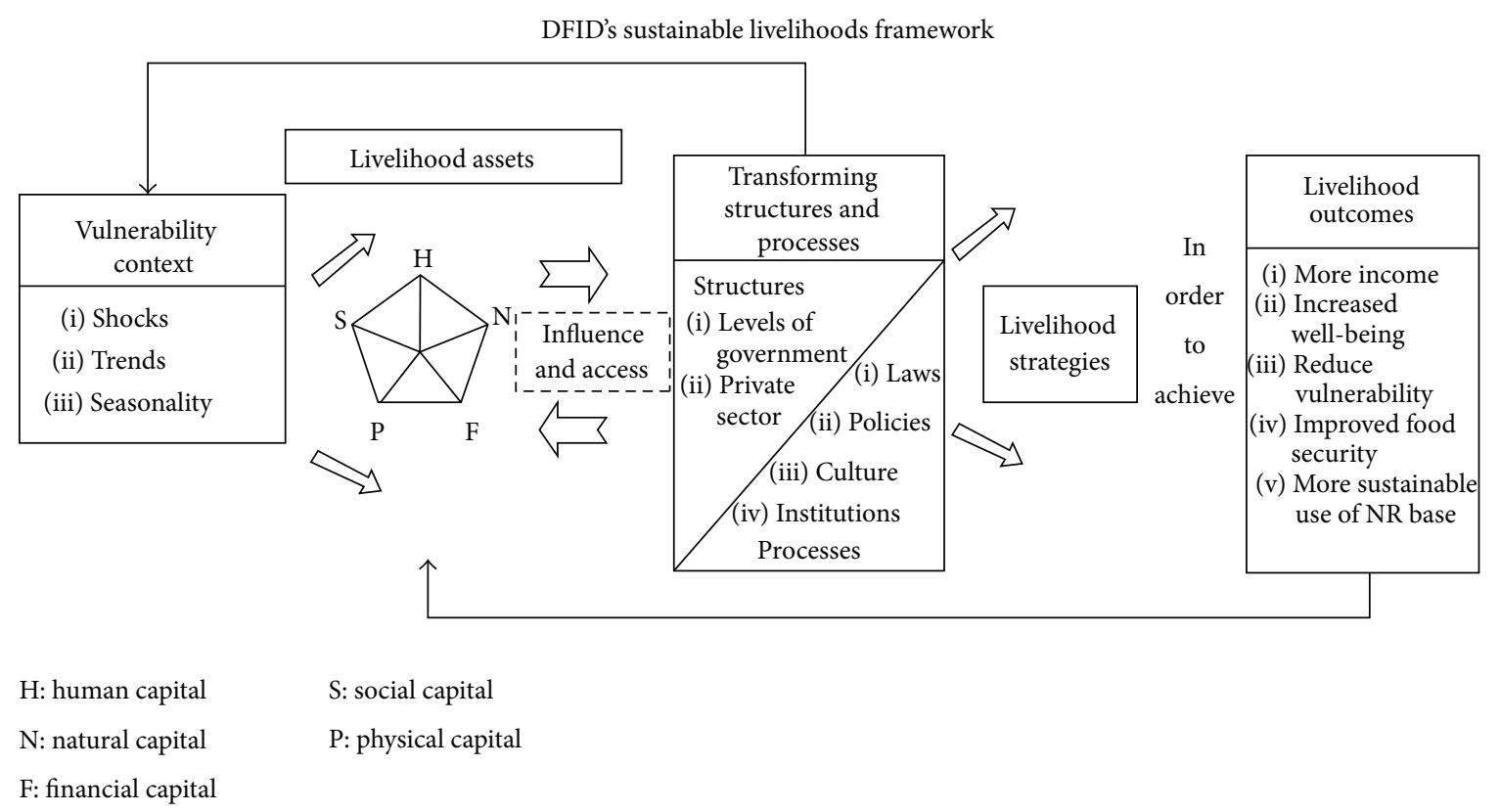

FIGURE 3: Sustainable Livelihoods Framework. Source: DFID [32] and Ashley and Carney [33].

underlie the forest-dissected plateau. Geologically, it is made up of two distinct rock formations, namely, the Birimian and the Tarkwaian rocks [22]. The study communities are underlain by the Precambrian metasediments of the Birimian rock (pelites, greywacke, and occasional volcanics) and Tarkwaian rock (conglomerates, quartzites, and phyllites). The Birimian rocks are viewed as the most important rock formation due to its mineral capacities [22]. This explains the existence of gold mining companies in the study area as well as increasing concentration of ASM. The major economic activities in the study area can be grouped into three categories: industries/mining, agriculture, and commerce. Mining is the major force that Prestea area relies upon in terms of employment. This profile of the study area, Prestea mining area, therefore, best illustrates the decision behind conducting this research in the area.

2.2. Theoretical Approach. To offer understanding of the relationship between mining activities and livelihoods, the sustainable livelihood approach (SLA) with DFID's sustainable livelihood framework (SLF) was adopted to guide the study. Many livelihood studies have adopted and applied the SLF approach giving grounds for development studies, thinking, and research [26]. This framework came into being as a result of debates and discussions on sustainable livelihood, poverty reduction, and assets [27-31]. Brundtland Commission on Environment and Development in 1987 was the first to put sustainable livelihood notion forward [28]. The concept of sustainable livelihood was then expanded by the 1992 United Nations Conference on Environment and Development, which advocated for the achievement of sustainable livelihoods as a goal for poverty eradication [28]. The SLF focuses on people and their livelihoods and how people can use their assets to realize their basic needs of life and reduce poverty $[32,33]$.
The SLF has five main components: vulnerability context (in terms of stress, shocks, and seasonality), livelihood assets, transforming structures and processes, livelihood strategies, and livelihood outcomes (see Figure 3). The variables in the framework show the linkages between the components and reflect how each component affects the other. The SLF shows that sustainable livelihoods are achieved through access to variety of livelihood sources such as natural capital (land) that are combined together in the pursuit of livelihood strategies to realize livelihood outcomes [33]. Livelihood strategies consist of a range and combination of activities and choices that people decide or undertake to achieve their livelihood goals. Livelihood strategies are dependent on asset endowments and policies, institutions, and processes in place [32]. The livelihood strategy that applies to this study is artisanal and small-scale gold mining activities.

The transforming structures and processes such as culture, laws, and policies in the framework are linked to the vulnerability context which in turn affects the livelihood assets available. Livelihood strategies such as ASM with various transforming structures and processes such as laws, policies, and culture influence livelihood assets which in turn help to enhance or reduce people's assets in the community. The institutions, policies, and customs of the transforming structure and processes in the framework enhance or hinder people's access to an asset or resource such as natural capital [32]. The livelihood outcomes in the framework are achieved as a result of livelihood strategies and are linked to livelihood assets to indicate how they enhance or increase them [33].

The assets in SLF show different forms of asset capital which people use to realize livelihood outcomes. The framework indicates that assets have five forms: natural, human, physical, financial, and social capital. DFID denotes assets as natural, physical, human, social, and financial capital. Assets are both created and destroyed as an upshot of 
trends, shocks, and seasonality of vulnerability context [32]. Assets' relationships with livelihood strategies illustrate that people with more assets tend to have range of options and ability to move between multiple strategies to secure their livelihoods as well as achieve positive livelihood outcomes [32].

The vulnerability context of DFID sustainable livelihood framework encompasses shocks, trends, and seasonality of livelihood strategies which in turn is linked to livelihood assets to show how it affects livelihood assets such as human capital and natural capital $[32,33]$. The vulnerability context in the framework represents the external environment in which people exist. Trends, shocks, and seasonality are the factors over which people have limited or no control [32]. Scoones [31] argues that the ability of livelihood to recover from stresses and shocks is key to sustainable livelihood. The usefulness of the sustainable livelihood framework to this research is its focus on livelihood outcomes, assets owned by people in their pursuit of livelihood strategies such as ASM activities, and vulnerabilities exposed to people [33]. In employing the SLF to analyze our research output, the study followed the appreciative inquiry approach to explore and describe the positive and negative outcomes of ASM $[34,35]$. This framework gives a better understanding and appreciation of the possible outcomes of mining activities on livelihoods and to make induction whether ASM is environmentally sustainable in Ghana. As Ashley and Carney [33] stressed, SLF provides a structure to help establish the understanding of livelihoods and how people cope with stresses, shocks, and seasonality in their quest to reduce or eliminate poverty. SLA is also important to this study due to its usefulness in ensuring that livelihood opportunities exist for the future generation yet unborn and helping us to identify and explore the assets and vulnerability context associated with ASM.

2.3. Research Design and Variables. In line with the theoretical and analytical orientation of the study, a cross-sectional survey with both quantitative and qualitative research design was employed. The qualitative research design involved the use of in-depth interviews, focus group discussion, and key informant interviews. The qualitative research approach used provided the avenue to assess the opinions and knowledge of people on ASM and livelihood issues. The study employed questionnaires for quantitative research design. The research instruments used made the survey easier and flexible to work with the research designs adopted. The independent variables constituted the demographic and socioeconomic characteristics of sex, age, education, occupation, income levels, marital status, ethnicity, religious belief, status of respondents, and the years a respondent has stayed in the study area. The dependent variable was livelihood outcome. The study variables were operationalized and further coded as indicated in Table 1 to ensure that the credibility, appropriateness, and accuracy of the data were established. ASM was conceptualized as an activity that covers small, medium, informal, legal, and illegal miners who use rudimentary methods, tools, and processes to extract valuable mineral resources from the earth's crust to enable them to obtain livelihood income and improve their living conditions.
2.4. Sampling and Study Participants. The study participants were individuals at the age of 18 and above, ASM workers, and farmers in Prestea mining region. Prestea, Bondaye, and Himan were the selected communities of Prestea mining enclave. The reason for this selection was based on proximity to mining sites and intensiveness of ASM activities in these communities. These study participants were our units of analysis. Community members at the age of 18 or above were contacted because they had adequate knowledge and information of ASM operations and its associations with livelihood contexts in terms of shocks, vulnerability, assets, and livelihood outcomes and policies. The minimum age threshold was also used because, at that age, every person could decide for themselves and participate in decision making at both local and national level.

A combination of simple random, purposive, and snowball sampling techniques was used for the study. The simple random sampling was used to select community members to respond to questionnaires. The residents were asked an initial question whether they were at the age of 18 and above or not before those who met the minimum age threshold and showed interest were recruited. Finally, a blind folded person was selected randomly and asked to pick the study participants. The snowball and purposive sampling methods were employed to select key informants: ASM workers and farmers. The ASM workers and farmers were selected purposively because this group of people and unit of analysis could be directly affected by ASM and would be in a better position to share their knowledge as well as voice out their concerns and worries.

The residents of Prestea, Bondaye, and Himan in Prestea mining region constituted the study population while residents aged 18 and above, farmers, and ASM workers constituted the sample frame. A sample size of 151 was used. Out of the 151, 53, 50, and 48 respondents were from Prestea, Himan, and Bondaye, respectively. The reason for the sample size from the study communities was based on unequal population size of the communities and response rate and deemed adequate for the research taking into consideration the objective of the study.

2.5. Research Instruments and Data Collection Process. For proper appreciation, analysis, and association between field data and the works that have already been conducted and documented as concerns the ASM, both primary data and secondary information were used for the study. The secondary information was obtained from published and unpublished documents such as books, journals, articles, and thesis. A pilot study was conducted in the three communities to help the testing of the reliability and validity of the instruments using SPSS Cronbach's reliability analysis and alpha value of 0.7 for the closed-ended questions which were meant for the quantification of the study results. This helped to reframe questions, clarify issues, and effect changes in the data. The primary data collected from the respondents were through face-to-face community-level intervieweradministered questionnaires, semistructured in-depth interview, and focus group discussions (FGDs) serving as the main 
TABLE 1: Operationalization and coding of the study variables.

\begin{tabular}{|c|c|c|c|}
\hline Variable & Operational definition & Category & Code \\
\hline \multirow{3}{*}{ Community } & \multirow{3}{*}{ Place of residence } & Bondaye & 1 \\
\hline & & Prestea & 2 \\
\hline & & Himan & 3 \\
\hline \multirow{2}{*}{ Sex (dichotomous) } & \multirow{2}{*}{ Being a male or female } & Male & 1 \\
\hline & & Female & 2 \\
\hline \multirow{6}{*}{$\begin{array}{l}\text { Age of respondents } \\
\text { (ranked) }\end{array}$} & \multirow{6}{*}{$\begin{array}{l}\text { Number of years attained by a respondent at his last } \\
\text { birthday }\end{array}$} & $<21$ years & 1 \\
\hline & & $21-30$ years & 2 \\
\hline & & $31-40$ years & 3 \\
\hline & & $41-50$ years & 4 \\
\hline & & $51-60$ years & 5 \\
\hline & & 60 years and above & 6 \\
\hline \multirow{3}{*}{$\begin{array}{l}\text { Status in the } \\
\text { community } \\
\text { (nominal) }\end{array}$} & \multirow{3}{*}{$\begin{array}{l}\text { Categorized as native (as born in the community), a } \\
\text { settler (a person who moves to the community to settle } \\
\text { permanently), or a migrant (just living in the } \\
\text { community for a short while or purpose) }\end{array}$} & Native & 1 \\
\hline & & Migrant & 2 \\
\hline & & Settler & 3 \\
\hline \multirow{3}{*}{$\begin{array}{l}\text { Marital status } \\
\text { (nominal) }\end{array}$} & \multirow{3}{*}{$\begin{array}{l}\text { Categorized as married, single, and divorced. Single } \\
\text { cohabitation is classified as married. Those who are not } \\
\text { married and widowhood are classified under single. } \\
\text { Those who are no more cohabiting are classified under } \\
\text { divorced }\end{array}$} & Married & 1 \\
\hline & & Single & 2 \\
\hline & & Divorced & 3 \\
\hline \multirow{5}{*}{$\begin{array}{l}\text { Occupation } \\
\text { (nominal) }\end{array}$} & \multirow{5}{*}{$\begin{array}{l}\text { A kind of economic activity that a respondent } \\
\text { undertakes to earn income }\end{array}$} & Trading & 1 \\
\hline & & Teaching & 2 \\
\hline & & Mining & 3 \\
\hline & & Fishing & 4 \\
\hline & & Others & 5 \\
\hline \multirow{5}{*}{$\begin{array}{l}\text { Educational level } \\
\text { (ranked) }\end{array}$} & \multirow{5}{*}{$\begin{array}{l}\text { A kind of educational level a respondent completed. } \\
\text { Dropout is where respondent could not complete basic } \\
\text { school }\end{array}$} & Basic & 1 \\
\hline & & Secondary education & 2 \\
\hline & & Tertiary education & 3 \\
\hline & & Drop-out & 4 \\
\hline & & Never been to school & 5 \\
\hline \multirow{5}{*}{ Ethnicity (nominal) } & \multirow{5}{*}{ The ethnic background/tribe of the respondents } & Akan & 1 \\
\hline & & Ewe & 2 \\
\hline & & $\mathrm{Ga}$ & 3 \\
\hline & & Northerners $^{\mathrm{a}}$ & 4 \\
\hline & & Others & 5 \\
\hline \multirow{4}{*}{ Religion (nominal) } & \multirow{4}{*}{ Religious affiliation of the respondents } & Christianity & 1 \\
\hline & & Islam & 2 \\
\hline & & African Traditional & 3 \\
\hline & & Others & 4 \\
\hline \multirow{5}{*}{ Income level (ranked) } & \multirow{5}{*}{$\begin{array}{l}\text { Income received monthly by respondents from all } \\
\text { sources including cash and gifts }\end{array}$} & Less than Ghథ 100 & 1 \\
\hline & & Ghథ $100-400$ & 2 \\
\hline & & $\mathrm{Gh} \pitchfork 401-1000$ & 3 \\
\hline & & Gh» 1001-2000 & 4 \\
\hline & & Above Gh₫ 2000 & 5 \\
\hline \multirow{4}{*}{$\begin{array}{l}\text { Number of years of } \\
\text { stay in the } \\
\text { community (ranked) }\end{array}$} & \multirow{4}{*}{$\begin{array}{l}\text { Number of years a respondent has stayed in the } \\
\text { community }\end{array}$} & Less than 5 years & 1 \\
\hline & & 5-10 years & 2 \\
\hline & & 11-15 years & 3 \\
\hline & & More than 15 years & 4 \\
\hline
\end{tabular}

${ }^{a}$ Northerners used in this context means the people of Mole-Dagbani, Guan, and Gurma ethnic groups of Ghana.

data collection instruments. The face-to-face communitylevel interviewer-administered questionnaires allowed us to avoid incompleteness of questionnaires, increase response rate, and obtain first-hand information and knowledge on ASM and livelihood. Three research enumerators were appointed and trained to help in the data collection process.
Six (6) and three (3) focus group discussions were formed for ASM workers and farmers, respectively, who were different from those who responded to the face-to-face communitylevel interviewer-administered questionnaires. Each group constituted eight (8) participants. In total, there were nine (9) groups of seventy-two (72) constituting 30 females and 
42 males. Also, to complement the FGDs, separate in-depth interviews were conducted for FGD participants with the help of research enumerators. This was done in order to touch on pertinent issues and things that the discussants could not disclose in the discussion section [36]. Three (3) farmers were selected from the focus groups for an in-depth interview. Seventy-nine (79) respondents answered a specific set of questionnaires in the three communities. The questionnaire focused on the factors that influence people's engagement in ASM, the category of people involved in it, the types of job opportunities created by ASM, and contribution of ASM to livelihood enhancement. FGDs and in-depth interviews also focused on the assets of ASM workers, how ASM affects farmers' and small-scale miners' source of income, vulnerability contexts, assets of ASM, ASM and environmental sustainability, and finally exploring the livelihood adaptation strategies. The questionnaires administration, FGDs, and interview were conducted in Wassa-Twi which is the main dialect of the people in the study communities. The questions were read in English and translated to WassaTwi but responses were written in English to ensure context validity. The FGDs and interviews were tape-recorded. This was done with the consent of participants. Field notes were also taken. Every focus group discussion lasted for about 1.5 hours. On average, each in-depth interview or administration of questionnaire took about 35 minutes.

2.6. Ethical Consideration. Social scientists are usually faced with ethical problems and cannot carry out research that involves people without any informed consent [37]. With regard to this, various ethical issues were considered and addressed before the field survey started. Field introductory letter was obtained from the Department of Geography and Rural Development, KNUST, Kumasi, Ghana. Verbal and informed consent was obtained from the study participants. The participants in the communities were briefly informed about the purpose of the research and guaranteed the anonymity of the information they provided.

2.7. Data Analysis. Both qualitative and quantitative tools were employed to analyze the empirical data obtained from the field. After the data collection, all tape-recorded interviews were screened and transcribed into English. The first author then read and reviewed all the field and interview notes and transcripts for comprehension. Predominant themes were collated and then analyzed using a combination of thematic and content analysis. The thematic and content analysis was used to identify recurring themes in the data, establish typologies of these themes, and find the variations and associations between and within the themes [38]. Some direct quotations from study participants were used to support the findings. Also, data were crosschecked with the original questionnaires, edited, and coded for analysis. The cross-check was done purposively to make any corrections. The quantitative data were then entered into an electronic database and analyzed statistically through the Predictive Analytics Software (PASW) for Windows application programmes (version 17.0). Descriptive statistics were used to describe the demographic and socioeconomic characteristics of the respondents and the thematic issues of ASM and livelihood. Bivariate methods of analyzing data were employed. A nonparametric Pearson's Chi-square $\left(\chi^{2}\right)$ test was conducted to compare demographic and socioeconomic independent variables (such as place of residence, age of respondents, status in the community, marital status, occupation, and sex). Other variables were compared with the study communities to establish the differences or relationship of outcomes of ASM. The interpretation of the results took into consideration the $p$ value of 0.05 or less as significant. Data were organized and presented using frequency tables and proportionate counts. Finally, the analytical techniques used for the study allowed us to make proper discussions, interpretations, and conclusions by triangulating the data with secondary information.

\section{Results}

3.1. Demographic and Socioeconomic Characteristics of Study Participants. Table 2 depicts the baseline characteristics of the study participants by sex status (for those who responded to the face-to-face community-level intervieweradministered questionnaires). Two hundred and eight (208) people were contacted but 151 people agreed to partake in the research. The response rate was approximately $73 \%$. Seventytwo of the total respondents (151) were engaged in discussion sessions of nine groups with eight members each consisting of 30 females and 42 males. The remaining seventy-nine (79) responded to face-to-face community-level intervieweradministered questionnaires which were quantified for the quantitative aspect of the study. However, for the quantitative aspect, nearly more than half $(50.6 \%, 40)$ of the respondents were females and $45.6 \%$ were within the age range of $31-40$ years. About 39\% were married with $69.6 \%$ Akans since the ethnic setting of the study prefecture is an Akan ethnic group. Most $(79.7 \%, 63)$ of the respondents professed Christian doctrines and faith; $35.4 \%$ were engaged in trading activities with $41.7 \%$ of respondents receiving a monthly income within GH\$ 100-400 (US\$ 33-133) (the exchange rate of Ghanaian Currency, Cedis (GHథ) per United States dollars as of the time of data collection and analysis (FebruaryMay, 2014)). A total of $40.5 \%$ of the respondents had a native status in the communities with $55.7 \%$ of respondents having stayed in these communities for more than 15 years while $9 \%$ had never been to school. Only small portion of the respondents (12.7\%) had attained tertiary education while $43 \%$ had achieved basic education as their highest on the educational ladder. Apart from mining with 19\% respondents, majority of the respondents were engaged in trading, farming, teaching, and others as livelihood strategies to achieve their livelihood goals. A statistical analysis was conducted to compare the demographic and socioeconomic characteristics of the respondents with respect to sex. A statistical significant difference between marital status and $\operatorname{sex}\left[\chi^{2}(2, N=79)=7.811, p=0.020\right]$, occupation and $\operatorname{sex}\left[\chi^{2}(4, N=79)=14.666, p=0.005\right]$, and educational level and sex $\left[\chi^{2}(4, N=79)=4.265, p=0.006\right]$ was established. 
TABLE 2: Characteristics of study participants by sex.

\begin{tabular}{|c|c|c|c|c|c|}
\hline \multirow[b]{2}{*}{ Variable } & \multirow[b]{2}{*}{ Category } & \multicolumn{3}{|c|}{ Sex } & \multirow[b]{2}{*}{$P$ value } \\
\hline & & $\begin{array}{l}\text { Male } \\
n(\%)\end{array}$ & $\begin{array}{c}\text { Female } \\
n(\%)\end{array}$ & $\begin{array}{c}\text { Total } \\
N(\%)\end{array}$ & \\
\hline \multirow{4}{*}{ Place of residence } & Bondaye & $12(15.2 \%)$ & $12(15.2 \%)$ & $24(30.4 \%)$ & \multirow{4}{*}{0.989} \\
\hline & Himan & $13(16.4 \%)$ & $13(16.5 \%)$ & $26(32.9 \%)$ & \\
\hline & Prestea & $15(19.0 \%)$ & $14(17.7 \%)$ & $29(36.7 \%)$ & \\
\hline & Total & $40(50.6 \%)$ & $39(49.4 \%)$ & $79(100 \%)$ & \\
\hline \multirow{7}{*}{ Age of respondents } & Less than 21 years & $2(2.5 \%)$ & $3(3.8 \%)$ & $5(6.3 \%)$ & \multirow{7}{*}{0.199} \\
\hline & $21-30$ years & $15(19.0 \%)$ & $10(12.7 \%)$ & $25(31.6 \%)$ & \\
\hline & $31-40$ years & $19(24.1 \%)$ & $17(21.5 \%)$ & $36(45.6 \%)$ & \\
\hline & $41-50$ years & $1(1.3 \%)$ & $7(8.9 \%)$ & $8(10.1 \%)$ & \\
\hline & $51-60$ years & $3(3.8 \%)$ & $2(2.5 \%)$ & $5(6.3 \%)$ & \\
\hline & 61 and above & $0(0 \%)$ & $0(0 \%)$ & $0(0 \%)$ & \\
\hline & Total & $40(50.6 \%)$ & $39(49.4 \%)$ & $79(100 \%)$ & \\
\hline \multirow{4}{*}{ Status in the community } & Native & $13(16.4 \%)$ & $19(24.1 \%)$ & $32(40.5 \%)$ & \multirow{4}{*}{0.198} \\
\hline & Migrant & $15(19.0 \%)$ & $8(10.1 \%)$ & $23(29.1 \%)$ & \\
\hline & Settler & $12(15.2 \%)$ & $12(15.2 \%)$ & $24(30.4 \%)$ & \\
\hline & Total & $40(50.6 \%)$ & $39(49.4 \%)$ & $79(100 \%)$ & \\
\hline \multirow{4}{*}{ Marital status } & Single & $20(25.3 \%)$ & $23(29.1 \%)$ & $43(54.4 \%)$ & \multirow{4}{*}{$0.020^{*}$} \\
\hline & Married & $20(25.3 \%)$ & $11(13.9 \%)$ & $31(39.3 \%)$ & \\
\hline & Divorced & $0(0 \%)$ & $5(6.3 \%)$ & $5(6.3 \%)$ & \\
\hline & Total & $40(50.6 \%)$ & $39(49.4 \%)$ & $79(100 \%)$ & \\
\hline \multirow{6}{*}{ Occupation } & Trading & $8(10.1 \%)$ & $20(25.3 \%)$ & $28(35.4 \%)$ & \multirow{6}{*}{$0.005^{*}$} \\
\hline & Teaching & $5(6.3 \%)$ & $3(3.8 \%)$ & $8(10.1 \%)$ & \\
\hline & Mining & $13(16.4 \%)$ & $2(2.5 \%)$ & $15(19.0 \%)$ & \\
\hline & Farming & $1(1.3 \%)$ & $3(3.8 \%)$ & $4(5.1 \%)$ & \\
\hline & Others & $13(16.5 \%)$ & $11(13.9 \%)$ & $24(30.4 \%)$ & \\
\hline & Total & $40(50.6 \%)$ & $39(49.4 \%)$ & $79(100 \%)$ & \\
\hline \multirow{6}{*}{ Educational level } & Basic & $17(21.5 \%)$ & $17(21.5 \%)$ & $34(43.0 \%)$ & \multirow{6}{*}{0.006} \\
\hline & Secondary & $13(16.5 \%)$ & $4(5.1 \%)$ & $17(21.5 \%)$ & \\
\hline & Tertiary & $6(7.6 \%)$ & $4(5.1 \%)$ & $10(12.7 \%)$ & \\
\hline & Drop-out & $4(5.1 \%)$ & $5(6.3 \%)$ & $9(11.4 \%)$ & \\
\hline & Never been to school & $0(0 \%)$ & $9(11.4 \%)$ & $9(11.4 \%)$ & \\
\hline & Total & $40(50.6 \%)$ & $39(49.4 \%)$ & $79(100 \%)$ & \\
\hline \multirow{5}{*}{ Ethnicity } & Akan & $23(29.1 \%)$ & $32(40.5 \%)$ & $55(69.6 \%)$ & \multirow{5}{*}{0.110} \\
\hline & Ewe & $6(7.6 \%)$ & $2(2.5 \%)$ & $8(10.1 \%)$ & \\
\hline & Northerners & $10(12.7 \%)$ & $4(5.1 \%)$ & $14(17.7 \%)$ & \\
\hline & Ga-Adangbe & $1(1.3 \%)$ & $1(1.3 \%)$ & $2(2.5 \%)$ & \\
\hline & Total & $40(50.6 \%)$ & $39(49.4 \%)$ & $79(100 \%)$ & \\
\hline \multirow{5}{*}{ Religion } & Christianity & $31(39.2 \%)$ & $32(40.5 \%)$ & $63(79.7 \%)$ & \multirow{5}{*}{0.379} \\
\hline & Islam & $6(7.6 \%)$ & $7(8.9 \%)$ & $13(16.5 \%)$ & \\
\hline & African traditional & $2(2.5 \%)$ & $0(0 \%)$ & $2(2.5 \%)$ & \\
\hline & Other & $1(1.3 \%)$ & $0(0 \%)$ & $1(1.3 \%)$ & \\
\hline & Total & $40(50.6 \%)$ & $39(49.4 \%)$ & $79(100 \%)$ & \\
\hline \multirow{6}{*}{ Income level } & Less than Gh₫ 100 & $4(5.1 \%)$ & $5(6.3 \%)$ & $9(11.4 \%)$ & \multirow{6}{*}{0.460} \\
\hline & Ghథ $100-400$ & $20(25.3 \%)$ & $13(16.5 \%)$ & $33(41.7 \%)$ & \\
\hline & Ghథ 401-1000 & $11(13.9 \%)$ & $16(20.3 \%)$ & $27(34.2 \%)$ & \\
\hline & Ghథ 1001-2000 & $4(5.1 \%)$ & $5(6.3 \%)$ & $9(11.4 \%)$ & \\
\hline & Above Ghథ 2000 & $1(1.3 \%)$ & $0(0 \%)$ & $1(1.3 \%)$ & \\
\hline & Total & $40(50.6 \%)$ & $39(49.4 \%)$ & $79(100 \%)$ & \\
\hline
\end{tabular}


TABLE 2: Continued.

\begin{tabular}{|c|c|c|c|c|c|}
\hline \multirow[b]{2}{*}{ Variable } & \multirow[b]{2}{*}{ Category } & \multicolumn{3}{|c|}{ Sex } & \multirow[b]{2}{*}{$P$ value } \\
\hline & & $\begin{array}{l}\text { Male } \\
n(\%)\end{array}$ & $\begin{array}{c}\text { Female } \\
n(\%)\end{array}$ & $\begin{array}{c}\text { Total } \\
N(\%)\end{array}$ & \\
\hline \multirow{5}{*}{ Number of years of stay in the community } & Less than $5 \mathrm{yrs}$ & $7(8.9 \%)$ & $7(8.9 \%)$ & $14(17.7 \%)$ & \multirow{5}{*}{0.517} \\
\hline & $5-10 \mathrm{yrs}$ & $9(11.4 \%)$ & $4(5.1 \%)$ & $13(16.5 \%)$ & \\
\hline & $11-15$ yrs & $4(5.1 \%)$ & $4(5.1 \%)$ & 8 (10.1\%) & \\
\hline & More than 15 yrs & $20(25.3 \%)$ & $24(30.4 \%)$ & $44(55.7 \%)$ & \\
\hline & Total & $40(50.6 \%)$ & $39(49.4 \%)$ & $79(100 \%)$ & \\
\hline
\end{tabular}

${ }^{*}$ The Chi-square statistic is significant at the 0.05 level.

The item validity for each variable is $100 \%$ (79) since the respondents answered all the questions.

3.2. ASM and Employment Opportunities. This section assessed the impact of ASM activities on employment opportunities. Table 3 depicts the results of bivariate analysis of employment issues of ASM for the study. Out of the 79 respondents, $59.5 \%$ strongly agreed that ASM has positive effect of creating job opportunities to people in mining communities while $7.6 \%$ (6) held a contrary view. However, there was no statistical significant difference between the effects of ASM on creating job opportunities in the three communities $\left[\chi^{2}(4, N=73)=8.748, p=0.068\right]$ as indicated in Table 3 . Majority (46.6\%) of the respondents indicated that both men and women were the major category of people involved in ASM while $24.6 \%$ of respondents argued for that of men, women, and children (see Table 3). Even though the study revealed that children constituted part of ASM workers, they were not permitted to engage in it. However, the study found no significant difference in category of people in ASM with respect to the study communities $\left[\chi^{2}(8, N=73)=9.212\right.$, $p=0.325]$. An in-depth interview with female ASM workers indicated that women were important in ASM because of their key role as head porters carrying mineral deposits (or gold mineralization materials) to mining sites, concession owners, gold dealers, machine owners, and cooking food for workers. Some women also found themselves at mining sites as mobile network credit, water, and food sellers.

Moreover, the respondents also reported that mining activities (45.2\%), food and water vending (19.2\%), gold dealing/gold smiting, driving (19.2\%), and head porters (13.7\%) were the major types of job opportunities created by ASM. Nearly more than half $(58.9 \%)$ of the respondents revealed that mining activities (such as chiseling, digging, and washing gold mineralization materials) and head porters served as an area where ASM provides direct jobs for people. Thus approximately four in ten of the respondents identified indirect job opportunities such as food vending and water selling, gold dealing and driving, machine owners, and others in study prefecture. However, the study results found a statistically significant difference between the types of job opportunities created by ASM as regards the study communities $\left[\chi^{2}(8, N=73)=15.786, p=0.046\right]$.

3.3. Driving Force of Taking Employment in ASM. Table 4 shows the major factors that drive people to take employment in ASM. Through multiple response scoring, the majority $(90.4 \%, n=66)$ noted that quick/high income generations from small-scale gold mining were the major factor that compels most people to engage in ASM. A significant percentage of $82.2 \%(n=60)$ indicated that limited or inadequate employment opportunities in rural areas influenced many people to engage in ASM. The third factor respondents expressed to have swayed people to seek job in it was the economic hardship/poverty situations of people in rural communities in the region (59\%). Also, about $20.3 \%$ of respondents indicated that the need to supplement income generated from other livelihood activities drove people into ASM activities.

3.4. Contribution of ASM to Livelihood Enhancement. Most (87.7\%) of the respondents said that people benefit from ASM's role of job creation. Nearly more than half (50.7\%) of the respondents expressed that ASM contributed to livelihood enhancement through income generations, increased well-being, and asset acquisitions such as building houses and ownership of cars. Others included reducing vulnerability (i.e., reducing poverty situations and rural exodus and any vulnerability in ASM) and empowerment, which were indicated by $31.1 \%$ and $19.2 \%$ of the respondents, respectively (see Table 3).

3.5. Effects of ASM on Household Income. Through FGDs, respondents indicated that ASM affected livelihood income both positively and negatively. All the discussants reported that ASM affected livelihood income positively by providing workers with high incomes and other people (such as taxi drivers, traders, and food vendors/water sellers) who indirectly depend on ASM for livelihood income, which further helps increase people's well-being and reduce food insecurity. Two of the discussants expressed this in different ways.

"Concentration of ASM in these communities does not only provide quick income or wage to residents and migrant ASM workers but also some people who by virtue use the increasing ASM activities as a means to sell food or other items to earn some income to cater for their families."

The other discussant also noted the following.

"There is no need for me to tell you about it... you can see it all for yourself that there are a lot of people engaging in it as well as many food 
TABLE 3: Results of bivariate analysis of ASM's employment issues and place of residence of respondents.

\begin{tabular}{|c|c|c|c|c|c|c|}
\hline \multirow[b]{2}{*}{ Variable } & \multirow[b]{2}{*}{ Category } & \multicolumn{4}{|c|}{ Place of residence of respondents } & \multirow[b]{2}{*}{$P$ value } \\
\hline & & $\begin{array}{l}\text { Bondaye } \\
n(\%)\end{array}$ & $\begin{array}{c}\text { Himan } \\
n(\%)\end{array}$ & $\begin{array}{l}\text { Prestea } \\
n(\%)\end{array}$ & $\begin{array}{l}\text { Total } \\
N(\%)\end{array}$ & \\
\hline \multirow{4}{*}{$\begin{array}{l}\text { Has ASM created } \\
\text { employment opportunities? }\end{array}$} & Strongly agree & $13(54.2 \%)$ & $18(69.2 \%)$ & $16(55.2 \%)$ & $47(59.5 \%)$ & \multirow{4}{*}{0.068} \\
\hline & Agree & $9(37.5 \%)$ & $4(15.4 \%)$ & $13(44.8 \%)$ & $26(32.9 \%)$ & \\
\hline & Disagree & $2(8.3 \%)$ & $4(15.4 \%)$ & $0(0 \%)$ & $6(7.6 \%)$ & \\
\hline & Total & $24(100 \%)$ & $26(100 \%)$ & $29(100 \%)$ & $79(100 \%)$ & \\
\hline \multirow{7}{*}{$\begin{array}{l}\text { What category of people are } \\
\text { involved in ASM activities? }\end{array}$} & Men & $3(13.6 \%)$ & $2(9.1 \%)$ & $7(24.1 \%)$ & $12(16.4 \%)$ & \multirow{7}{*}{0.325} \\
\hline & Women & $0(0 \%)$ & $1(4.5 \%)$ & $0(0 \%)$ & $1(1.4 \%)$ & \\
\hline & Children & $0(0 \%)$ & $0(0 \%)$ & $0(0 \%)$ & $0(0 \%)$ & \\
\hline & Men and women & $13(59.1 \%)$ & $12(54.5 \%)$ & $9(31.1 \%)$ & $34(46.6 \%)$ & \\
\hline & Women and children & $3(13.6 \%)$ & $2(9.1 \%)$ & $3(10.3 \%)$ & $8(11.0 \%)$ & \\
\hline & Men, women, and children & $3(13.6 \%)$ & $5(22.7 \%)$ & $10(34.5 \%)$ & $18(24.6 \%)$ & \\
\hline & Total & $22(100 \%)$ & $22(100 \%)$ & $29(100 \%)$ & $73(100 \%)^{1}$ & \\
\hline \multirow{6}{*}{$\begin{array}{l}\text { What type of job } \\
\text { opportunities has ASM } \\
\text { created? }\end{array}$} & Mining activities (gold extracting and processing) & $11(50.0 \%)$ & $6(27.3 \%)$ & $16(55.2 \%)$ & $33(45.2 \%)$ & \multirow{6}{*}{$0.046^{*}$} \\
\hline & Food and water vending & $2(9.1 \%)$ & $8(36.4 \%)$ & $4(13.8 \%)$ & $14(19.2 \%)$ & \\
\hline & Gold dealing and drivers & $2(9.1 \%)$ & $6(27.3 \%)$ & $6(20.7 \%)$ & $14(19.2 \%)$ & \\
\hline & Head porters & $5(22.7 \%)$ & $2(9.1 \%)$ & $3(10.3 \%)$ & $10(13.7 \%)$ & \\
\hline & Others & $2(9.1 \%)$ & $0(0 \%)$ & $0(0 \%)$ & $2(2.7 \%)$ & \\
\hline & Total & $22(100 \%)$ & $22(100 \%)$ & $29(100 \%)$ & $73(100 \%)$ & \\
\hline \multirow{3}{*}{$\begin{array}{l}\text { Do people benefit from the } \\
\text { ASM employment } \\
\text { opportunities? }\end{array}$} & Yes & $20(90.9 \%)$ & $20(90.9 \%)$ & $24(82.8 \%)$ & $64(87.7)$ & \multirow{3}{*}{0.584} \\
\hline & No & $2(9.1 \%)$ & $2(9.1 \%)$ & $5(17.2 \%)$ & $9(12.3 \%)$ & \\
\hline & Total & $22(100 \%)$ & $22(100 \%)$ & $29(100 \%)$ & $73(100 \%)$ & \\
\hline \multirow{5}{*}{ If yes, how? } & Reducing economic hardships & $6(27.3 \%)$ & $6(27.3 \%)$ & $12(41.4 \%)$ & $24(32.9 \%)$ & \multirow{5}{*}{$0.005^{*}$} \\
\hline & Reducing poverty & $1(4.5 \%)$ & $10(45.5 \%)$ & $10(34.5 \%)$ & $21(28.8 \%)$ & \\
\hline & Income generation & $15(68.2 \%)$ & $5(22.7 \%)$ & $7(24.1 \%)$ & $27(37.0 \%)$ & \\
\hline & Other & $0(0 \%)$ & $1(4.5 \%)$ & $0(0 \%)$ & $1(1.3 \%)$ & \\
\hline & Total & $22(100 \%)$ & $22(100 \%)$ & $29(100 \%)$ & $73(100 \%)$ & \\
\hline \multirow{4}{*}{$\begin{array}{l}\text { Contribution of ASM to } \\
\text { livelihood enhancement }\end{array}$} & Income generations and increased well-being & $16(72.7 \%)$ & $9(40.9 \%)$ & $12(41.4 \%)$ & $37(50.7 \%)$ & \multirow{4}{*}{0.171} \\
\hline & Reduced vulnerability & $3(13.6 \%)$ & $8(36.4 \%)$ & $11(37.9 \%)$ & $22(30.1 \%)$ & \\
\hline & Empowerment & $3(13.6 \%)$ & $5(22.7 \%)$ & $6(20.7 \%)$ & $14(19.2 \%)$ & \\
\hline & Total & $22(100 \%)$ & $22(100 \%)$ & $29(100 \%)$ & $73(100 \%)$ & \\
\hline
\end{tabular}

${ }^{1} 73$ apply to those who only agreed ASM generated employment opportunities out of the total 79 . The item validity for the variables answered by 73 study respondents is $92.4 \%$ (73).

*The Chi-square statistic is significant at the 0.05 level.

TABLE 4: Major factors or reasons that drive people to take employment in ASM.

\begin{tabular}{lcc}
\hline Category & Frequency $(N=73)^{\mathrm{a}}$ & Percentage \\
\hline Limited or inadequate employment opportunities in rural areas & 60 & $82.2 \%$ \\
Economic hardships/poverty situations of people & 43 & $58.9 \%$ \\
Low income earnings in agriculture & 10 & $13.7 \%$ \\
Quick/high income generations from ASM & 66 & $90.4 \%$ \\
Supplement income generated from other livelihood activities & 16 & $20.3 \%$ \\
\hline
\end{tabular}

\footnotetext{
${ }^{a}$ Multiple responses were possible; sum of percentage is more than $100 \%$.
} 
vendors, traders and drivers. It has significant impact on income that is why we have many food vendors, gold dealers, women head porters, machine owners and drivers around. I hope you know by now why people are rushing into ASM."

Small-scale miners stated their average monthly income. Majority (33.3\%) of the participants reported that they earned monthly income within GH\$ 401-500 (US\$ 133-167). They further expressed that they even earned more than what they reported. The participants reported that there were uneven monthly income earnings in ASM due to the type of activity the miners undertake, gold price, and varying nature of income earnings from the activities. They indicated that male small-scale miners earned more income than female miners.

Majority of the participants from the FGDs indicated that, irrespective of the high income earned from the activities, they were still exposed to some vulnerability that they could not totally get rid of. Most participants reported that when ASM workers were exposed to occupational hazards, diseases, accidents, and injuries, which further exposed them to ill health and could not work anymore, their livelihood/household incomes were adversely affected or destroyed. The participants also revealed that artisanal and small-scale gold mining, especially "galamsey," caused destruction to farmlands and livelihood income sources of other people who depended on the land. From the FGDs, this is what one of the discussants had to say:

\begin{abstract}
"When we sustain injuries or accidents and cannot work again, our source of income is destroyed and because of this we stay in the house doing nothing and depend on relatives and friends for survival or to help us get money to buy food to eat. Sometimes workers are killed in the course of ASM operations. You have reminded me of my brother who died in an underground pit when the roof of a cave collapsed and fell on him."
\end{abstract}

Majority of the participants reported that knowing the stresses, shocks such as injuries, accidents, and changes in weather did not influence their decisions to engage in ASM. This was in line with a statement made by a female worker in an interview. She stated that

"No matter what you do to stop injuries, deaths and accidents in the operations, it will always happen. They are always associated with the ASM. Injuries, accidents and deaths are no more news to workers and the community. We have coped for years and understand we cannot do anything about them. The work is risky. Poverty is what has caused me to work as a head porter to earn GH\$ 10.00 (US\$ 3.3) a day."

Nonetheless, the female participants in the focus groups revealed that economic hardships and poverty were the driving factors that compelled many women to engage in ASM in order to cater for their family and improve upon their living conditions. Results from FGDs and in-depth and informant interview revealed that small-scale farm holders were also prime victims who severely suffer from mining activities, particularly, illegal gold mining, and at times lose their livelihood income via destruction of farmlands/arable lands. Several others expressed their views, especially a 50 -year-old female farmer in an in-depth interview who expressed her views in the following words:

"I am a farmer and have farmed for so many years
but the presence of ASM activities in the town,
Bondaye has destroyed many of my farmlands,
especially my sugarcane farm which provided me
a source of income to help send my children to
school. I believe ASM has greatly destroyed many
farmers' household income and is still having
negative effects on us."

It became clear that ASM workers had some knowledge on ASM activities and their effects on people and the natural environments.

3.6. Livelihood Assets Associated with ASM. The participants stated the critical assets associated with ASM activities which people combine and use to achieve their livelihood objectives. The various assets the participants indicated are summarized in Table 5. Most of the participants noted that natural asset was the most valuable asset since, without land and forest, financial capital in the form of income cannot be obtained to help access basic needs of life. On the contrary, some participants argued against this view that, without human strength and ingenuity, gold mineral deposits would remain in the earth and cannot be extracted and processed to earn household income. Most participants reported that social capital in its various forms was the least important capital to workers' assets. The participants further indicated that social capital such as social institutions, church, kinship, and family, was the most important capital asset to residents when making reference to the community as a whole and dealing with relationships. They held that miners depended on family members, friends, neighbours, and social institutions for support and assistance (in various forms such as cash and gifts) in difficult times to cope with shocks and stresses.

3.7. Vulnerability Context of ASM. Table 6 presents a summary of the diverse ways in which ASM is vulnerable to mankind and affects critical assets. Most participants cited that human capital (man) and natural capital (farmland) were most vulnerable livelihood assets usually compromised by ASM. The participants indicated that diseases and occupational hazards such as injuries, accidents, and deaths were the shocks found in ASM activities in the study area. The miners indicated cough, tuberculosis, waist and muscle pains, asthma, skin rashes, malaria, and respiratory diseases as the common health problems they experienced through ASM operations. The discussants' narrative accounts indicated that ASM caused some trends of vulnerability in ASM, which would lead to future livelihood insecurity.

Air and noise pollutions were also found as induced vulnerability. Majority of discussants indicated that changes in weather destruct and affect their activities and household income. Fluctuation of gold prices was found to have negative 
TABLE 5: Assets associated with ASM and miners.

\begin{tabular}{|c|c|}
\hline Type of asset capital & Critical assets associated with or in ASM \\
\hline Natural capital & $\begin{array}{l}\text { (i) Land containing gold mineralization that enables mining activities to be undertaken. } \\
\text { (ii) Forest providing timber/woods for the activities. } \\
\text { (iii) Mineral deposits in the land/earth crust. } \\
\text { (iv) Water bodies (such as rivers) for washing gold mineral materials and processing. }\end{array}$ \\
\hline Physical capital & $\begin{array}{l}\text { (i) Chemicals such as mercury and cyanide for processing and extracting gold. } \\
\text { (ii) Equipment/tools used in operation-chisels, truck, shovels, hammers, touch lights, sacks, gold mill machines, } \\
\text { bulldozers, water pumping machines, and excavators. } \\
\text { (iii) Roads serving as a mode of transport for conveying miners, traders, and loads. } \\
\text { (iv) Shelter camps at mining sites. }\end{array}$ \\
\hline Human capital & $\begin{array}{l}\text { (i) Men's knowledge and skills applied in the extracting processes. } \\
\text { (ii) People's ability to work or function in ASM. } \\
\text { (iii) Diverse group of people in the capacity as miners, drivers, trader, engineers, administrative staff, chisellers, } \\
\text { and others. } \\
\text { (iv) Physical strength of people used in ASM. }\end{array}$ \\
\hline Financial capital & $\begin{array}{l}\text { (i) Cash and income earnings as salaries or wage from the activities. } \\
\text { (ii) Savings from the activities. } \\
\text { (iii) Capital (loans) investment into ASM operations. }\end{array}$ \\
\hline Social capital & $\begin{array}{l}\text { (i) Miners' and employees' networking. } \\
\text { (ii) Miners' individual social relationships and friendship. } \\
\text { (iii) Social organisations and kinship. } \\
\text { (iv) Emotional support via comforting and others. }\end{array}$ \\
\hline
\end{tabular}

TABLE 6: Vulnerability of ASM activities to assets and the community.

Critical asset affected by ASM

Land

Water bodies

Human
Vulnerability induced by ASM in mining communities

(i) Destruction of farmlands/arable lands which results in food insecurity/low agricultural produce.

(ii) Creating of uncovered pits which serve as breeding grounds for mosquitoes to cause malaria.

(iii) Destruction of fertile lands, biodiversity, and the natural forest.

(i) Destruction of fishing grounds which serve as livelihood source.

(ii) Destruction of community's sources of water.

(iii) Contamination of water bodies with chemicals such as mercury and cyanide leading to water-borne diseases such as skin rashes, diarrhoea, and cholera.

(i) Diseases and injuries, accidents, and death as a result of workers' or miners' exposure to ASM related hazards.

(ii) Destruction of miners' livelihood source and/or income through injuries and accidents which further renders them poor.

(iii) Destruction of farmers' livelihood income via destruction of farmlands and arable lands. repercussions on miners' earnings, wages, and household income. They identified rainy season as the major seasonality that slows down small-scale mining activities in Prestea mining area. Mining pits become filled with water during rainy seasons. ASM workers noted that this caused concession owners to spend money to pump the water from the underground pits to allow any mining activities to be done. They also expressed that those who employ open cast method or surface mining were not greatly affected as compared to alluvial gold mining and underground or open cut mining.

3.8. ASM and Environmental Sustainability. Majority of the participants indicated that ASM in the study area did not ensure sustainable use of natural resources. Participants' accounts indicated that increasing activities of ASM were causing rapid destruction to farmlands, fertile soils, water bodies, biodiversity, and forest resources in Prestea mining enclave and Ghana as a whole. Small-scale miners noted that majority of miners in the study area did not have concessions and licenses to operate. Most of the miners pondered over how they could meet their basic needs of life if they stopped small-scale mining or illegal mining all in the name of ensuring sustainable environment. Some of them also recommended that large-scale underground mining must be introduced so that they would stop illegal mining and still have their livelihood source whiles ensuring environmental sustainability in Prestea mining area. One of the ASM workers noted the following:

"If the government cannot open many jobs in the country, then they should not think of tackling environmental sustainability in ASM. ASM is lucrative to people like us who do not have skills to engage in formal sector. We have to engage in ASM as our livelihood activity and will try to reduce our impact on the environment and if possible change the method of operation." 
3.9. Livelihood Adaptation and Coping Strategies. Majority of the participants reported that ASM workers who sustain injuries or experience occupational hazards as shocks and lose their livelihood income depend on social relations and personal networks such as friends and family for survival and assistance in order to take care of basic necessities of life. Miners who lose their livelihood through injuries and accidents withdraw their savings to enable them to establish businesses or engage in petty-trading as their new livelihood activity. Also, the miners who lose their livelihood source sell their personal assets to enable them to engage in other forms of livelihood strategies. Some miners try as much as possible to avoid occupational related hazards such as injuries and accidents during work hours so that they would not lose their household income forever.

However, the participants also stated that some farmers intensify their few available farmlands to increase agricultural produce and income. Other farmers also abandon their farmlands destroyed by mining and migrate to nonmining communities to search for farmlands for cultivation of crops. Regular health check-ups are adopted by some small-scale miners to help them maintain their health and seek treatment for their health problems such as muscle and waist pains, cough, asthma, and respiratory diseases. Participants' narrative accounts revealed that some residents in the study area filter and boil water collected from rivers and streams which are contaminated through mining activities before using it at their homes or do not use water from rivers and streams at all. This activity is adopted by few people who are perceived to be poor. They also noted that the study communities cope with ASM's adverse effect of contamination and destruction of water bodies using pipe-borne water and sachet water and digging wells to get water for their domestic activities.

Furthermore, artisanal and small-scale miners indicated that they cope with changes in weather especially rainy season, by using pumping machines to collect water from mining pits to make a way for them to do their work. Few discussants said that some miners have employed surface and alluvial gold mining as methods of mining due to its less exposure to occupational hazards as compared to underground or open cut mining. Miners also try to cope with the shocks by educating among themselves about the risks of the work and to be cautious during work periods.

\section{Discussion}

The current study explored the nexus between ASM and livelihood using data from Prestea mining region, Ghana. Understanding livelihoods of poor people and their assets is critical to eliminating poverty [33]. The study demonstrates that concentration of ASM attracts migrants to the PMR. The study found that, apart from mining activities in Prestea mining area, a significant percentage of residents were engaged in other livelihood activities such as food vending, water selling, farming, and others as a means to achieve their livelihood goals. The low percentage (12.7\%) of respondents who had attained tertiary education coupled with dropouts (11.4\%) and those who had never been to school (11.4\%) could be the reason why many of the respondents were engaged in the informal sector such as petty-trading, farming, food vending, and apprenticeships. The study, however, established that the type of occupation or livelihood strategies adopted by the residents in the study area have a statistical significant association with sex.

The study found that most respondents (43\%) had attained basic education as their highest level of education. This could be attributed to the fact that concentration of ASM in the area did not allow many indigenes to further their education to secondary and tertiary level. This finding is akin to researches conducted elsewhere in the world. For example, Hentschel et al. [11] in their research in Bolivia found that small-scale mining has adverse effects on people's educational status. The study found that ASM has created/opened employment opportunities and that it has provided both direct and indirect employment to indigenes and migrants in Prestea mining area. It was unearthed that ASM provides direct employment opportunities to people as engineers, chisel men, processors, and head porters. It also offers indirect employment opportunities to people as water sellers, food vendors, taxi drivers, gold dealers/gold smiths, and traders, among others. These findings are in consonance with previous researches that show that mining provides both direct and indirect employment $[2,15,21,39]$. Direct employment opportunities created by ASM, however, outweigh indirect job opportunities in the PMR. It is therefore not doubtful that Ofei-Aboagye et al. [39] indicated that about $60 \%$ of mining labour is employed within artisanal and small-scale mining operation sites. Researchers such as OfeiAboagye et al. [39] and CASM [6] recognize that small-scale mining engages more people than large scale mining. The study participants' responses show a statistically significant difference between the types of employment opportunities created by ASM in relation to the study communities.

Small percentage of the study participants added children as part of people involved in small-scale mining. Children's involvement is attributed to the fact that the operations provide quick income or cash to people and this influences some children to engage in it to earn some money. Although there are some laws that forbid child labour, children still engage in it. Mitullah et al. [14], in their research in the Migori District of Kenya, concluded that some children skip classes to work as miners to obtain money. Some children engage in it to help their poor parents. The study shows that women's involvement in small-scale mining is important. They are found in the aspect of carrying mineral deposits to washing sites, washing gold mineralization materials, concession owners, and gold dealers and cooking food for miners since they cannot involve themselves in the physical strength aspect of the operations. Poverty and economic hardships are the factors that drive women to participate in smallscale mining in order to improve their living conditions. This supports Hinton et al. [40] assertion that, for most women, ASM symbolizes an avenue to reduce strains of poverty. Undoubtedly, Hilson [15] and Hinton et al. [40] underscored that gender related activities in ASM have increased women's involvement.

The study discovered that limited employment opportunities or lack of jobs in rural areas, economic hardships/poverty, 
quick/high income earnings from ASM, low income earnings in agriculture, and supplementing income generated from other livelihoods were the driving factors that compelled and influenced people to combine and use their personal assets to enable them to engage in artisanal and small-scale mining in Prestea mining region. Limited job opportunities or lack of jobs was seen as the reason for high influx of people from the length and breadth of Ghana to the study area. Since jobs are not available, coupled with low earnings in agriculture and severe economic hardships in the country, many people have resorted to ASM in the study area to help them achieve their basic necessities of life. This supports Amankwah and AnimSackey [2] statement that low income earning and paying jobs or nonexistence of jobs in rural areas make small-scale mining a valuable source of employment for many people. The study reveals a contrary finding to that of Hentschel et al.s [11] studies in Bolivia that stress that seasonality of agriculture has caused many rural people in mining communities to engage in ASM to sustain their livelihood throughout the year. The study found that low income earnings in agriculture have caused some farmers to abandon their activity to engage in small-scale mining. The difference in the findings may be attributed to differences and occupations in the study settings and methodology used.

The severe rural poverty/economic hardships, low income earnings in agriculture, and unemployment are mostly the driving vulnerability factors that influence people to engage in ASM activities. However, these three key factors that drive many people to combine and use their personal assets to undertake ASM activities trigger induced vulnerabilities. The induced vulnerabilities such as injuries and accidents and destruction of farmlands and water bodies are also believed to cause subsequent vulnerability. For instance, miners who get injuries and accidents through the activities expose them to ill health and further cause some to lose their livelihood sources or income and finally worsen their poverty situations. This creates some trends of vicious cycle of vulnerability from driving vulnerability to induced vulnerability, subsequent vulnerability, and future vulnerabilities. The study results have shown that small-scale mining contributes to livelihood enhancement through income generations, increased well-being and asset acquisitions, reduced vulnerability, and empowerment of people to establish their own businesses and take initiatives to improve their lives. The study demonstrates that ASM reduces vulnerability by providing people with income to buy food, which in turn reduces food insecurity and improves living conditions. It also reduces poverty situations and helps people, particularly miners, to seek treatment for their mining related health problems such as muscle and waist pains, cough, and malaria through the income earned from their activities. This finding has come to support previously conducted studies [2]. The study indicates that ASM as a livelihood strategy benefits or supports people through increased income and reduction of vulnerabilities. These are evident in DFID's sustainable livelihood framework [32].

The study found that ASM affects livelihood income positively by providing income to miners and other people. This provides sufficient income to households to take care of their needs and family. This lends support to the assertion made by Amankwah and Anim-Sackey [2] that ASM has positive effects on livelihood through income generations to both miners and other people, and the operations are alternative income generating employment. High income earnings in ASM in Prestea mining communities are skewed towards the men since the men perform the difficult aspects of ASM activities, enabling them to earn more income or wages than women.

The study also found that small-scale mining has adverse effects on livelihood/household income as induced vulnerability through destruction of farmlands which causes some farmers, especially small-scale farm holders, to lose their livelihood and household income which in turn render some to extreme poverty. This is due to the unregulated illegal mining activities in the area. This lends support to previous research output that indicates that agriculture as a source of livelihood income for rural indigenes is altered and, to a large extent, destroyed [5]. Those who lose their livelihood source and/or income experience extreme poverty. However, Adjei [41] expressed that farmers who are adversely affected by mining activities maintain their livelihood by pursuing other livelihood activities such as petty-trading and through support (via cash and gifts) from friends and relatives. The study found destruction of many farmlands/arable lands by ASM as a major factor that caused food insecurity and low agricultural produce and food crops in the area. This is consonant with other studies conducted elsewhere. For example, Ocansey [17] in his studies in Kyebin concluded that mining activities have taken up fertile lands and destroyed farmlands and livelihood which in turn lead to food shortages. Akabzaa and Darimani [5] stress that degradation of farmlands in the Tarkwa Mining Township coupled with migrant workers causes food prices to be high. Mitullah et al. [14] also support our findings that farmers who shift their attention from agriculture activities to mining as their new occupation due to lower income generation in agriculture in rural areas cause reduction in food production.

Water pollution and contamination were another effect of ASM on livelihood in PMR. This was due to the fact that most ASM activities in the study area used water and were undertaken in water bodies. Most water bodies that served as sources of water for domestic and agricultural activities such as drinking, cooking, and irrigating farms have been destroyed in the PMR. This has reduced the communities' access to safe water, hence, causing water shortage problems. It is not surprising that previous studies indicated that smallscale mining destroys sources of water with chemicals such as cyanide and mercury and render them unsafe for domestic activities [19, 21, 42-44].

ASM also affects livelihood/household income when small-scale miners lose their livelihood income through occupational hazards such as injuries, accidents, and diseases and cannot work anymore. The study identified injuries, deaths, accidents, and diseases as the shocks in ASM. This affirms Stephens and Ahern [45] statement that mining remains the most dangerous occupation in terms of injuries, accidents, and death. It was found that small-scale miners are most vulnerable when they sustain injuries, accidents, 
and diseases. Due to how the activities are conducted and done, many small-scale miners are exposed to these occupational hazards and mining related diseases such as skin rashes, tuberculosis, waist and muscle pains, and respiratory diseases. Changes in weather, especially rainy season, were identified as the major seasonality associated with ASM. Rainy season poses dire threat to ASM activities which slows down operations and subsequently affects household income. It also causes workers to lose their employment when the rainy season is severe and prolonged for longer period.

Fluctuation of gold prices was identified as a trend in ASM that affects household income and has subsequent effects on workers' assets. The study illustrates that critical assets affected by ASM pose threat to human development and natural environment. ASM destroys fertile lands, water bodies, biodiversity, and natural forest as well as creating uncovered pits and trenches. These problems of water pollution, destruction of fertile soils, and vegetation induced by ASM make it difficult to ensure environmental sustainability and sustainable use of the natural resource base. The increasing activities of ASM are degrading and destroying the forest which is contributing to climate change and undermining Reducing Emissions from Deforestation and Forest Degradation (REDD+) initiatives. The deforestation and forest degradation by ASM sector is making it difficult for Forest Commissions to ensure sound and effective forest management in Ghana.

However, albeit artisanal and small-scale mining has the potential of generating employment and income to many people, especially, rural people, it defies the principle of environmental ethics and sustainability and destroys livelihood income of people. This finding illustrates that livelihood should not only look at meeting basic needs but also consider sustainability in the three-model table, environment, economy, and development, as Morelli [46] expressed. The study reveals that weak policies regulating artisanal and small-scale gold mining in Ghana are also responsible for the increasing environmental problems. Due to this, nonGhanaians, particularly, Chinese immigrants, have trooped themselves into illegal small-scale mining, hence, increasing the environmental impacts of ASM in the country. This finding has emerged to support Suleman and Agyemang's [47] assertion that there are weak legal and policy frameworks that regulate small-scale mining activities in many countries in the world.

Also, economic hardships and lack of employment opportunities or unemployment in rural areas were believed to have caused many miners to overlook the small-scale mining regulations. Drawing from Chamber and Conway [29], a livelihood is considered as sustainable when it can cope with and recover from stresses and shocks and maintain or enhance its capacities and assets while not undermining the natural resource base and also providing sustainable livelihood opportunities for the next generation yet unborn. This assertion serves as a base to conclude that ASM activities in Ghana, particularly, PMR, cannot be seen as sustainable livelihood. This is because ASM activities in the study communities are increasingly undermining the natural resource base and causing widespread environmental degradation, even though people have coped with the shocks and stresses in the ASM. The study found that people's knowledge and awareness of the shocks do not influence their decision to engage in ASM. This is because miners' main concern is to get some money to access basic needs of life and reduce their poverty situations.

The study found that there are different kinds of assets in ASM and that people combine and use these assets to enable them to engage in small-scale mining to achieve their livelihood goals. Natural capital in the form of land, mineral deposits, and water bodies enables miners with their human capital (skills, strength, and efforts) and mining tools and equipment to extract and process gold mineralization materials obtained from the land. Natural capital was, however, indicated by the small-scale miners as the most valuable asset since, without land, water bodies, and forest resources, financial capital in the form of income or cash cannot be obtained with human strength and ingenuity. This assertion is, therefore, in contrast to Sen [27] who argues that what a person can do or does with his or her personal features, manpower, skills, and knowledge to improve his standard of living is what matters most in life but not the availability of commodities or assets (such as minerals). Mining equipment and tools, sacks, trucks, and cyanide and mercury as processing chemicals were revealed by the study as physical capital which people use to realize their livelihood goals. Cash or income earnings and capital investment as well as miners' savings are the financial capital in ASM. This capital is important to miners because it is the main reason why they engage in ASM in order to have the means to access basic necessities of life-shelter, food, and clothing to improve their living conditions. However, some of the income earned from ASM (as financial capital) is reinvested in the operations through purchasing of mining equipment and tools (physical capital) in order to increase the earnings. Social capital was identified as social relations, friends, family, and networks, that miners rely upon when they have any problem and need assistance. This is what Ellis [48] indicated as important capital when someone needs support or assistance for survival. These capital assets are the various livelihood assets identified by DFID [32]. However, these assets show a significant relationship with small-scale mining activities. The study discovered that those who lose their livelihoods through accidents and injuries depend on social relations for support and assistance for survival or basic needs of life. This is consistent with earlier research output [5].

The strength of this study lies in its combination of quantitative and qualitative research design involving simple random and purposive sample techniques. The use of DFID's SLF as the guide to this study also served as a strength in assessing the nexus between artisanal and small-scale mining and livelihood in the PMR, Ghana. The use of qualitative appreciative inquiry approach in this paper helped to establish clear understanding of vulnerabilities in ASM and the various ways people adapt to cope with stresses and maintain their livelihood conditions. The study encountered some limitations. Some study participants were reluctant to be interviewed by the research enumerators. There could be a sample bias due to the small sample size used for the study. 
This has the potential to influence the study results in one way or the other.

\section{Conclusion}

This study explored the nexus between artisanal and smallscale mining and livelihood in Prestea mining region, Ghana. Quick/high income earning from ASM, limited job opportunities in rural areas, economic hardships/poverty scenarios of people, and low earnings in agriculture are the main reasons why most people or miners engage in ASM. Economic hardships and poverty are the driving factors that sway and force many women to engage in mining activities to assist them in catering for their family and improving their living conditions. Direct employment opportunities created by ASM for people outweigh indirect jobs such as driving and food vending in mining communities. However, the study has shown that there is no difference with the effects of ASM on job creation in mining communities of Ghana. It has also shown that small-scale mining contributes to livelihood enhancement through income generation, increased well-being, asset acquisitions, reduced vulnerabilities, and empowering of people to establish their own businesses and take initiatives to improve their lives. It reduces poverty situations and rural exodus in the area. However, injuries, diseases, accidents, and deaths, rainy season, and fluctuation of gold prices are the vulnerability context in ASM. Weak policies regulating ASM create an avenue for many people to combine and use their personal assets to enable them to engage in it as livelihood strategy to generate positive livelihood outcomes. The study shows that livelihood assets can be enhanced and destroyed by small-scale mining activities. ASM adopted by rural people destroys livelihood assets through destruction of farmlands and forest and water resources. High income from ASM shows a connection among assets, vulnerability context, and livelihood outcomes where high income earnings increase people's financial capital and reduce vulnerability such as poverty situations and food insecurity. Destruction of fertile lands, water bodies, farmlands, and forest resources by mining poses dire threat to sustainable development and environment. The study therefore concludes that there is a clear nexus (both positive and negative) between ASM and livelihood. The findings will therefore improve people's understanding of ASM with its links to livelihood assets and vulnerability context of livelihood.

\section{Recommendations}

As Solesbury [49] indicated, sustainable livelihood approach provides a three-way street triangle of research, policy, and practice which informs each other. With regard to this, the study provides recommendations which in turn would affect policies and assist policy makers in implementing appropriate measures to ensure sustainable mining activities in Ghana. Firstly, the study recommends that land policies in Ghana should be reviewed to incorporate land reclamation and refill and reforestation programmes in mining communities to ensure sustainable small-scale mining activities. The Government of Ghana in collaboration with Environmental
Protection Agency (EPA) must employ trained personnel as a monitoring team to help ensure that small-scale miners conform to mineral and land regulations. Secondly, the EPA should collaborate with the local government at the district level to create buffer zone to limit or stop ASM activities from being undertaken in water bodies so that destruction and contamination of water bodies would be reduced in the country. Also, small-scale miners should adopt proper and modern methods in their operations in order to minimize their impact on the environment.

There should be law enforcement by the EPA, Mineral Commissions, and local authorities to protect farmlands so that farmers will not lose their livelihoods through illegal small-scale mining. Again, opinion leaders and chiefs should collaborate with the Prestea-Huni Valley District to initiate borehole and well construction programmes to increase accessibility of water in PMR, Ghana. Moreover, nongovernmental organisations, the EPA, and various media such as television and radio stations should organise seminars to create awareness on ASM and its effects on livelihood and the environment to help small-scale miners understand the need to ensure environmental sustainability in their quest to achieve their livelihood goals.

Furthermore, in order to minimize the vulnerability and susceptibility to livelihood insecurities, the core structures involving government and private agencies ought to focus on reducing poverty and unemployment as well as induced vulnerability. These structures must create enabling environment for more job opportunities. Investment into areas such as rural industries, education, agriculture, and construction works helps to reduce economic hardships and unemployment, which are the forces compelling many people to involve in illegal small-scale mining in Ghana. Policy makers should not only look at the ramifications of ASM activities but also incorporate ASM sector into poverty reduction strategies in Ghana to provide significant number of job opportunities to people and an avenue to reduce poverty.

\section{Conflict of Interests}

The authors declare that there is no conflict of interests regarding the publication of the paper.

\section{Acknowledgments}

The authors express their heartfelt gratitude to the research enumerators for their assistance in the data collection process. Special thanks are due to Rosemary Arthur for her financial support. Much appreciation also goes to Abrefa Kwaku Busia and Vincent Boanor for their comments and inspiration.

\section{References}

[1] A. MacDonald, Industry in Transition: A Profile of the North American Mining Sector, International Institute for Sustainable Development, 2002.

[2] R. K. Amankwah and C. Anim-Sackey, "Strategies for sustainable development of the small-scale gold and diamond mining 
industry of Ghana," Resources Policy, vol. 29, no. 3-4, pp. 131-138, 2003.

[3] G. Hilson, "Small-scale mining and its socio-economic impact in developing countries," Natural Resources Forum, vol. 26, no. 1, pp. 3-13, 2002.

[4] D. Ulrike, G. Franken, M. Liedtke, and H. Siever, "Artisanal and small-scale mining (ASM)," POLINARES Working Paper 19, POLINARES, 2012.

[5] T. Akabzaa and A. Darimani, "Impact of mining sector investmentin Ghana: a study of the Tarkwa Mining Region," Drafted Report for SAPRI, 2001, http://www.saprin.org/ghana/research/ gha_mining.pdf.

[6] Collaborative Group on Artisanal and Small-Scale Mining (CASM), 2003, http://en.wikipedia.org/wiki/Artisanalmining collaborative_group_on_Artisanal_and_small_scale_mining_ 28CASM.2.

[7] International Labour Organisation (ILO), "Social and labour issues in small-scale mines," in Proceedings of the Tripartite Meeting on Social and Labour Issues in Small-Scale Mines (TMSSM '99), Geneva, Switzerland, October 1999.

[8] B. N. A. Aryee, "Contribution of minerals and mining sector to the national development: Ghana's experiment," Great Insights, vol. 1, no. 5, 2012.

[9] Ghana Chamber of Mines, "The impact of mining on local economy," Annual Report of the Chamber of Mines, Accra, Ghana, 2005.

[10] World Bank, "Mongolia: a review of environmental and social impacts in the mining sector," 2006, http://siteresources.worldbank .org/INTMONGOLIA/Resources/Mongolia-Mining.pdf.

[11] T. Hentschel, F. Hruschka, and F. Priester, "Global report on artisanal and Small scale mining," Working Paper 70, Minerals and Sustainable Development (MMSD) Project, London, UK, 2002.

[12] S. Datta, V. Mahajan, and G. Thakur, An Introduction to Livelihood Promotion, Rural Finance Centre, 2004.

[13] A. Y. Iddrisu and F. S. Tsikata, "Mining sector development and environment project," Regulatory Framework study to assist small miners, prepared for the mineral commissions, 1998.

[14] W. V. Mitullah, J. S. Ogola, and M. A. Omulo, "The socioeconomic aspects of Artisanal Gold mining in Migori District, Kenya," in The Socio-Economic Impacts of Artisanal and SmallScale Mining in Developing Countries, G. Hilson, Ed., pp. 260270, Taylor and Francis Publications, London, UK, 2003.

[15] G. Hilson, "A Contextual Review of the Ghanaians Small-scale Mining Industry. Mining, Minerals and Sustainable Development Project," 2001, http://pubs.iied.org./pdfs/G00722.pdf.

[16] R. K. Amankwah and W. K. Buah, "Some metallurgical aspects of small-scale gold mining in Ghana," in Proceedings of the Extraction Metallurgy Africa '98 Conference, pp. 1-4, South African Institute of Mining and Metallurgy, 1998.

[17] I. T. Ocansey, Mining impacts on agricultural lands and food security. Case study of towns in and around Kyebi in the Eastern Region of Ghana [Bachelor Thesis], Turku University of Applied Sciences, Turku, Finland, 2013.

[18] J. Y. Yeboah, Mining Activities in Obuasi, Ghana: Environmental and Health Impacts, LAP LAMBERT Academic Publishing, Saarbrucken, Germany, 2011.

[19] M. A. Bessah, Effects of small-scale gold mining on water resources: a case study of Bogoso/Prestea mining area [M.S. thesis], Kwame Nkrumah University of Science and Technology (KNUST), Kumasi, Ghana, 2011.
[20] T. M. Akabzaa, J. S. Seyire, and K. Afriyie, The Glittering Façade: Effects of Mining Activities on Obuasi and Its Surrounding Communities, Third World Network Africa (TWN-Africa), Accra, Ghana, 2007.

[21] J. Opoku-Ware, The social and environmental impacts of mining activities on indigenous communities: the case of Newmont Gold (Ghana) Limited (Kenyasi) in Ghana [M.S. thesis], University of Agder, Kristianland, Norway, 2010.

[22] Prestea/Huni-Valley District Assembly (PHDA), Prestea/HuniValley Assembly Medium Term Development Plan (2010-2014), Planning Unit, Prestea/ Huni-Valley District Assembly, 2010.

[23] Ghana Statistical Service (GSS), Ghana Population and Housing Census 2010, Ghana Statistical Service (GSS), Accra, Ghana, 2012.

[24] Golden Star Bogoso Prestea Limited (GSBPL EMP), "Surface and ground water monitoring project," Environmental Management Plan, pp. 13-15, 2008.

[25] Mapping Unit, Department of Geography and Rural Development, Kwame Nkrumah University of Science and Technology, Kumasi, Ghana, 2015.

[26] A. Shankland, "Analysing policy for sustainable livelihood," IDS Research Report 49, IDS, Brighton, UK, 2000.

[27] A. Sen, The Standard of Living, The Tanner Lectures, Clare Hall, Cambridge, UK, 1985, Cambridge University Press, Cambridge, UK, 1987.

[28] World Commission on Environment and Development (WCED), Report on World Commission on Environment and Development: Our Common Future, United Nations, New York, NY, USA, 1987.

[29] R. Chambers and G. Conway, "Sustainable rural livelihoods: practical concepts for the 21st century," IDS Discussion Paper 296, IDS, Brighton, UK, 1992.

[30] G. Carswell, "Agricultural intensification and sustainable rural livelihoods: a think piece," Working Paper 64, IDS, Brighton, UK, 1997.

[31] I. Scoones, "Sustainable rural livelihoods: a framework for analysis," Working Paper 72, IDS, Brighton, UK, 1998.

[32] Department for International Development, Sustainable Livelihoods Guidance Sheet, Department for International Development (DFID), London, UK, 1999.

[33] C. Ashley and D. Carney, Sustainable Livelihoods: Lessons from Early Experience, Department for International Development, London, UK, 1999.

[34] D. Cooperrider and D. Whitney, "The appreciative inquiry summit: an emerging methodology for whole system positive change," Journal of the Organization Development Network, vol. 32, pp. 23-26, 2000.

[35] G. R. Bushe, "Appreciative inquiry is not (Just) about the positive," OD Practitioners, vol. 39, no. 4, pp. 30-35, 2007.

[36] J. Corbin and J. M. Morse, "The unstructured interactive interview: issues of reciprocity and risks when dealing with sensitive topics," Qualitative Inquiry, vol. 9, no. 3, pp. 335-354, 2003.

[37] M. Israel and I. Hay, Research Ethics for Social Scientists: Between Ethical Conduct and Regulating Compliance, Pine Forge Press, London, UK, 2006.

[38] G. Graffigna and K. Olson, "The ineffable disease: exploring young people's discourse about HIV/AIDS in Alberta, Canada," Qualitative Health Research, vol. 19, no. 6, pp. 790-801, 2009. 
[39] E. Ofei-Aboagye, N. M. Thompson, S. Al-Hassan, T. Akabzaa, and C. Ayamdoo, "Putting miners first: understanding the livelihoods contexts of small scale and artisanal mining in Ghana," Synthesis Report, 2004, http://r4d.dfid.gov.uk/pdf/outputs/C392 .pdf.

[40] J. J. Hinton, M. M. Veiga, and C. Beinhoff, "Women and artisanal mining: gender roles and the road ahead," in The Socio-Economic Impacts of Artisanal and Small-Scale Mining in Developing Countries, G. Hilson, Ed., pp. 161-203, Taylor \& Francis Publications, London, UK, 2004.

[41] E. Adjei, Impact of mining on the livelihoods of rural households: a case study of farmers in the Wassa mining region [M.S. thesis], Norwagian University of Science and Technology, 2007.

[42] A. G. N. Kitula, "The environmental and socio-economic impacts of mining on local livelihoods in Tanzania: a case study of Geita District," Journal of Cleaner Production, vol. 14, no. 3-4, pp. 405-414, 2006.

[43] P. N. Owens, R. J. Batalla, A. J. Collins et al., "Fine-grained sediment in river systems: environmental significance and management issues," River Research and Applications, vol. 21, no. 7, pp. 693-717, 2005.

[44] S. Phiri, Impact of artisanal small scale gold mining in Umzingwane district (Zimbabwe): a potential for ecological disaster [M.S. thesis], University of the Free State, Bloemfontein, South Africa, 2011.

[45] C. Stephens and M. Ahern, "Worker and community health impacts related to mining operations internationally," Tech. Rep. 25, IIED, 2001.

[46] J. Morelli, "Environmental sustainability: a definition for environmental professionals," Journal of Environmental Sustainability, vol. 1, no. 1, article 2, 2011.

[47] I. Sulemana and I. Agyemang, "The socio-cultural implications of small-scale mining in the Talensi-Nabdam district of the Upper East Region of Ghana," International Research Journal of Public and Environmental Health, vol. 2, no. 3, pp. 27-36, 2015.

[48] F. Ellis, Rural Livelihood Diversity in Developing Countries, Oxford University Press, Oxford, UK, 2000.

[49] W. Solesbury, "Sustainable livelihoods: a case study of the evolution of DFID Policy," Working Paper 217, Overseas Development Institute, London, UK, 2003. 


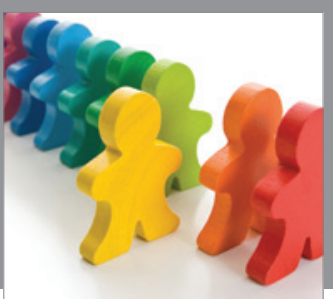

Autism

Research and Treatment
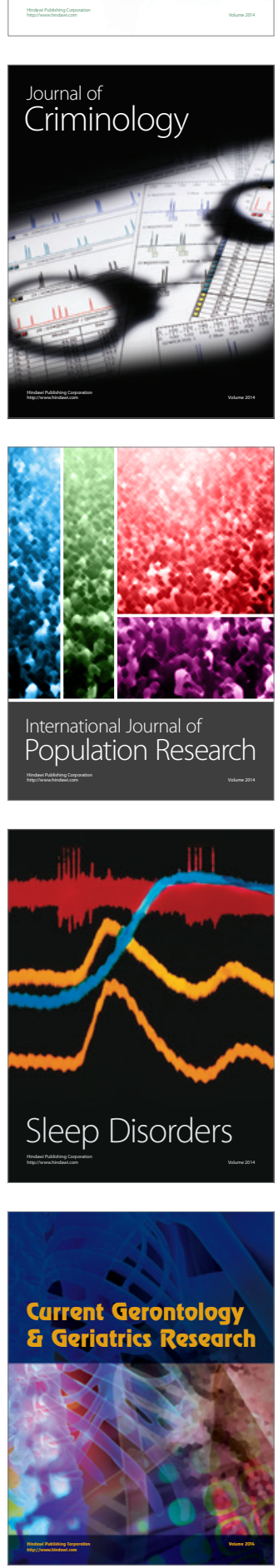

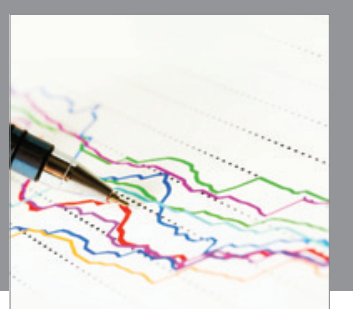

Economics

Research International
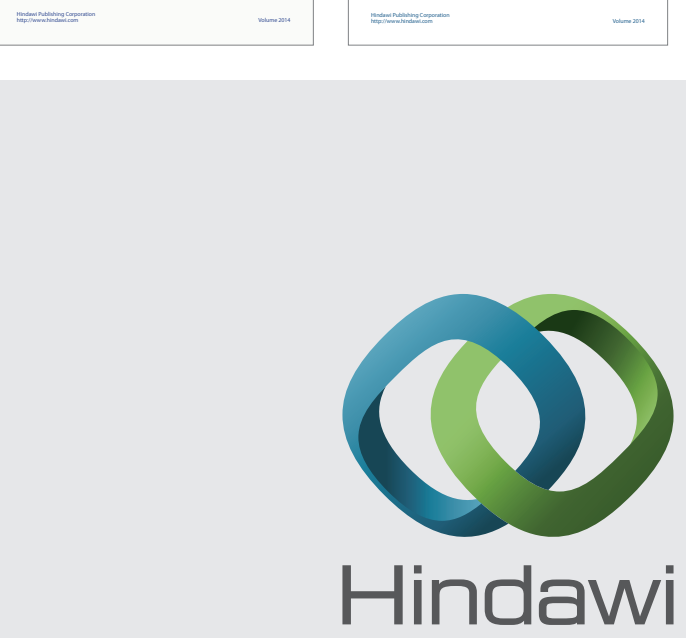

Submit your manuscripts at

http://www.hindawi.com
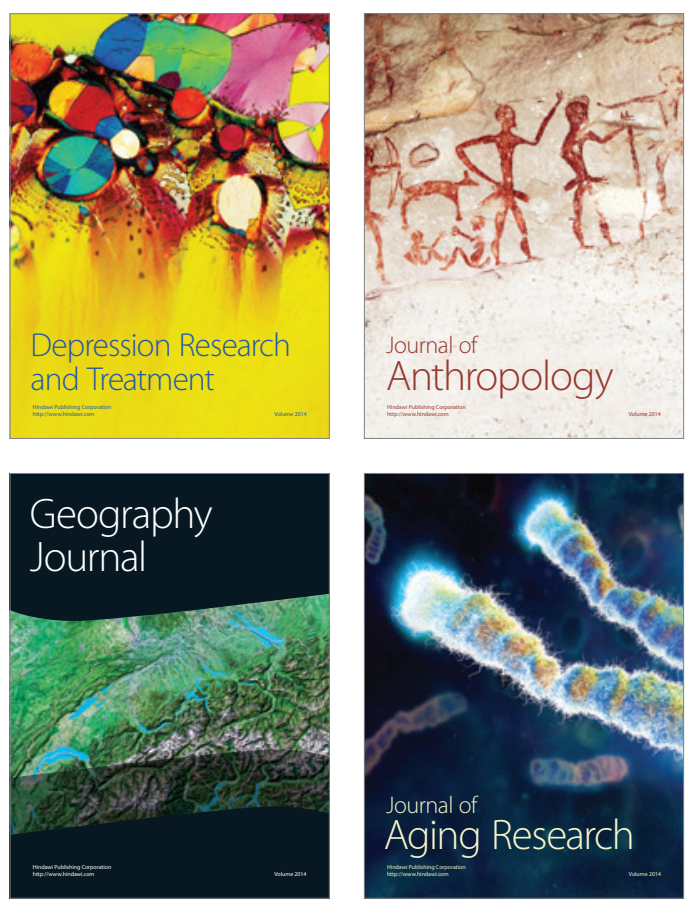
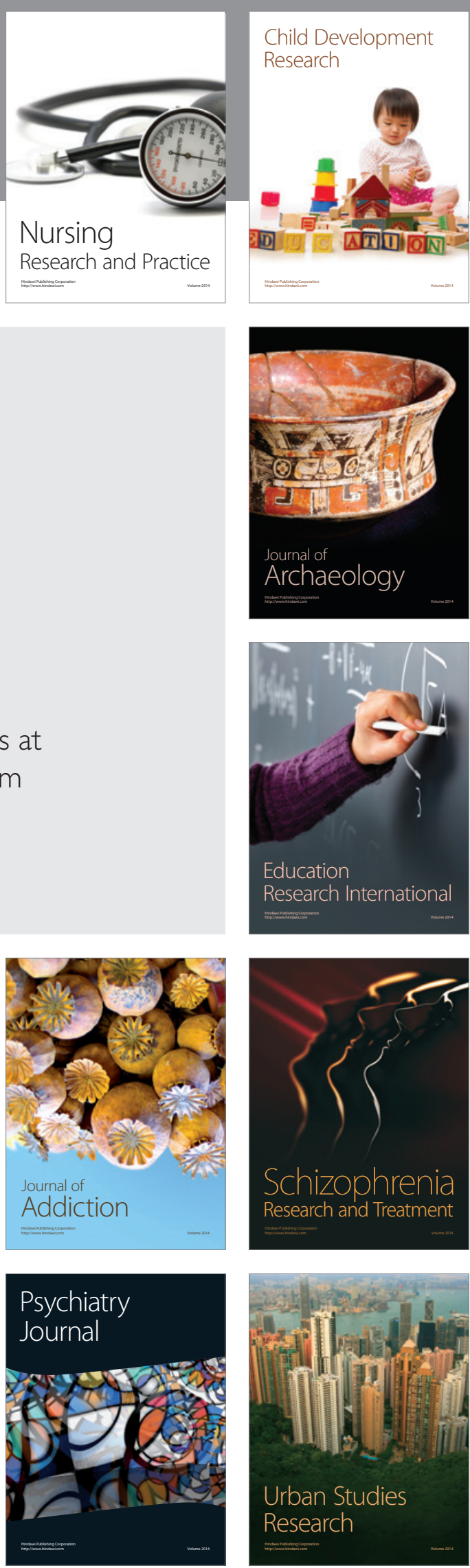